DOI:10.24193/tras.SI2018.5

Published First Online: 2018/12/28

\section{GOVERNMENT ACCOUNTING EDUCATION FOR UNIVERSITY UNDERGRADUATES}

\author{
Ileana Cosmina PITULICE \\ Alina Georgiana PROFIROIU \\ Aurelia ȘTEFĂNESCU
}

\section{lleana Cosmina PITULICE}

Associate Professor, Department of Accounting and Audit, School of Accounting and Management Information Systems, Bucharest University of Economic Studies, Bucharest, Romania E-mail: ileana.pitulice@cig.ase.ro

\section{Alina Georgiana PROFIROIU}

Professor, Department of Administration and Public Management, School of Administration and Public Management, Bucharest University of Economic Studies, Bucharest, Romania E-mail: alina_profiroiu@yahoo.com

Aurelia ȘTEFĂNESCU (corresponding author)

Professor, Department of Accounting and Audit, School

of Accounting and Management Information Systems,

Bucharest University of Economic Studies, Bucharest, Romania Tel.: 0040-744-273.543

E-mail: aurelia.stefanescu@cig.ase.ro denced the following issues: (1) the students' option (choice) for employment in public administration depends on their opinion on this field and the preponderance of certain disciplines in the undergraduate program's curricula; (2) the undergraduates' employment status does not influence their opinion on public administration; (3) the difficulty of transactions' accounting recognition in government accounting requires a greater volume of time in the curricula.

Keywords: public administration, undergraduate students, government accounting education.

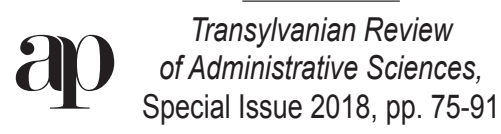




\section{Introduction}

The idea of this research derives from the discrepancy between the trend of transformations in the public administration sector and the academic and accounting professional environment. All these changes are circumscribed to the New Public Management policy, which is one of the most important reforms in the public sector during the last 30 years (Hințea, Profiroiu and Țiclău, 2015). As a consequence of the New Public Management, an important change took place in the financial reporting of Romanian public sector entities: transfer from cash accounting to accrual accounting. The accrual accounting concept offers a more transparent, reliable and fair view on public sector's financial reporting. Thus entities' management can fundament decisions on relevant, trusty, opportune and transparent information for an efficient distribution of public resources and an increased credibility of citizens.

However, the studies performed evidenced that among the multiple causes of distortion of the true and fair view in financial reporting there are: insufficient professional training of professionals employed in financial-accounting departments, the insufficient number of professionals in public sector entities, the difficulty of recruiting well trained accounting professionals due to the low level of salaries, limited professional judgment of accountants in financial-accounting departments, incorrect interpretation of accounting regulations (...) (Pitulice and Ștefănescu, 2016). These were generated by the radical changes in accounting regulations for the Romanian public sector, regulations that were incomplete in terms of accrual accounting adoption (Tiron-Tudor, Nistor and Carstea, 2012) and of reduced comparability with International Public Sector Accounting Standards (Tiron-Tudor, 2010). In this context, a pertinent analysis of the present educational system and professional training and a realistic approach of curricula are needed.

From the accounting profession point of view, the Body of Experts and Licensed Accountants of Romania (CECCAR) are also involved in the training of the future accounting professionals in the government accounting field. An argument in this respect is the inclusion of government accounting discipline (GA) in the syllabus required for the potential CECCAR Experts' access examination.

As an exception to the ordinary regulation, accounting professionals activating in public sector entities are not required to become CECCAR members. Also, public services' employees cannot activate as CECCAR experts, and those working in the public sector are required to declare themselves as non-active members. Under this perspective, there is a small number of accounting professionals employees that are also CECCAR members in the public administration sector. Therefore, the access to continuing development training programs offered by CECCAR expert status is limited, as well as the relationship with the accounting profession environment.

Regarding the academic environment, the number of teaching hours for GA in the curricula of the School of Accounting and Management Information Systems (AMIS part of the Bucharest University of Economic Studies) has decreased in the last years. The Bucharest University of Economic Studies is the only Romanian university hav- 
ing almost exclusively economic specializations, activating for more than a century in the Romanian academic environment and, for that reason, the AMIS school is representative for the number of undergraduates/ graduates.

GA as a discipline has been shifted from the second year of study to the third year (final year), when the interest of students is quite low for anything not related to Financial Accounting which is their main option for the Bachelor's degree thesis. In this respect, in the university environment, there is a recognized need to increase the Romanian students' interest and involvement in the learning process (Profiroiu, 2013).

Thus, the research idea was to investigate the opinion of the senior year in respect to GA as part of the AMIS undergraduate curricula and their perception on GA's importance in their undergraduate curricula.

\section{Literature review}

Government accounting education is approached in a limited manner in accounting literature. Globalization and changes generated by NPM require a new profile for accounting professionals and also the curricula's update.

The release of a major review on accounting higher education emphasizes the following milestones: (a) curricula and course content are expected to be more open and relevant to the economic environment; (b) pedagogical techniques need to promote creativity rather than memorization; (c) development of generic skills; (d) focus on technology for decision making; (e) strengthen faculty development and reward systems; (f) implementing strategic directions to enforce the importance and usefulness of general accounting education (Albrecht and Sack, 2000). University accounting education should be focused not only on technical accounting issues, but also on developing personal skills and competencies that generally help students - future graduates - to be successful in their careers (Hurt, 2007).

If business accounting education has been constantly reviewed so that it can face the challenges of a permanent changing economic environment, government accounting education has not been updated in the same rhythm. In the past few decades, demand for an advanced government accounting education has increased, due to several factors, such as deficiencies in governmental audits, the issuance of complex public sector accounting and auditing standards as well as the need for highly trained professionals in public sector entities (Wilson, 2013).

The challenge faced by universities when updating the curricula so that they can develop government accounting together with other types of accounting is that of capturing students' interest for this subject (Miller, 2006). Different accounting treatments and techniques for governmental financial reporting, as well as the low interest of undergraduate students in developing a public sector career lead to a very small emphasis on this study subject.

The public accounting course is sometimes considered the 'ugly stepsister' within the accounting curricula. Some colleges and universities include this discipline within an undergraduate program, others offer it as an elective course. There are cases when 
it is offered as an abbreviated one-credit course. This happens in terms of a global rise of government accounting due to an increased demand for accountability by the democratic and market economies, which is a reality for a few decades (Chan, 2003). Henry (2005) considers that the academic response to the increasing needs of highly trained professionals in the government accounting field was minimal. The exposure of business students to government and not-for-profit accounting did not increase with the same speed as the development of these two sectors. A study from 2007 investigates the perceptions of professors regarding the relative importance of governmental and non-profit accounting topics coverage in an undergraduate accounting course. Major findings such as slow curricula redesign, lower convergence of the profession demands or lack of appropriate time to cover all materials, generated some conclusions: the need for innovative learning methods and a permanent critical assessment of structure, content and presentation methods (Daniels, Gupta and Pridgen, 2007).

Specific Romanian research had demonstrated the usefulness of accrual accounting and added arguments for the increasing implication of accounting in the public sector management and its importance to the efficiency and effectiveness of public sector management (Deaconu, Nistor and Filip, 2011).

In 2015, the National Agency of Civil Servants from Romania (NACS) had conducted a national research study in order to assess the connection between the higher education quality perception and the labor market requirements. The sample focused on 240 students, from 20 Romanian universities. Almost 25\% of the respondents express a critical opinion about the public administration system, $44 \%$ of respondents would like to work in Romania or to continue their studies and 2/3 would consider a career in public administration, the main reason being the job stability. More than $45 \%$ of respondents considered that their academic training is strongly correlated with the job requirements for public servants, legal courses being more relevant than the management ones. On the other hand, the majority of the respondents consider that the academic programs are mostly focusing on technical knowledge and competences, whereas competences and skills in communication and public relations need to have a higher weight within the curricula (NACS, 2015). From this point of view, the NACS's findings are not convergent to those in our research, but the explanation could be that of the students' profile: while NACS's research questioned public administration undergraduates, our research is based on accounting undergraduates' responses. However, in what regards the opinion towards public the administration system we concluded that our research is convergent to that of NACS as a consequence of the high percent of the respondents offering low-ranking answers or being undecided.

\section{Research objective}

The choice of the research goal was supported by the idea that GA should not remain just an isolated discipline in public administration programs' curricula, but it has to get more and more importance as the public sector follows the same trend of globalization. Moreover, the need for efficient governance and transparency requires 
well trained employees, professionals who bring a plus of reliability to the public sector entities reporting.

We set three objectives in our research, each one of them being tested through several hypotheses. The objectives and the hypotheses derived from them are listed below and the results of their testing are extensively described in the empirical results section.

Objective 1: Examine if undergraduate students' decision of being employed in the public sector is determined by their opinion towards this domain and the curricula's orientation on public sector particularities.

H1. There is a connection between undergraduate students' choice of being employed in the public administration and their opinion about public administration. (Q1-Q2)

H.1.1. Undergraduate students' interest for getting a job in public administration is low.

H2. There is a connection between undergraduate students' choice of being employed in the public administration and the typology of courses in their program's curricula. (Q2-Q4)

H6. There is a connection between undergraduate students' employment status and their opinion about the public sector. (Q1-Q16)

H8. There is a connection between the typology of courses studied by undergraduate students and the choice of getting employed in the public sector. (Q2-Q3)

Objective 2: Examine if undergraduate students' interest for GA is determined by the time volume allocated in the program's curricula.

H3. There is a connection between undergraduate students' assessment of GA's particular concepts and the time volume allocated to this discipline. (Q6-Q9)

H4. There is a connection between the undergraduate students' assessment of transactions' recognition in GA and the time volume allocated to this discipline. (Q7-Q9)

H5. There is a connection between the undergraduate students' choice for advanced GA courses and the usefulness of studying adjacent information. (Q8-Q11)

Objective 3: Examine undergraduate students' opinion on the competencies delivered by the program's curricula as being correlated or not to the requirements of the labor market.

H7. There is a connection between the undergraduate students' employment status and the mandatory competencies to be included in the curricula. (Q5-Q16)

\section{Research methodology}

The sample analyzed in this research paper consists of 279 students from the senior year of AMIS School, Bucharest University of Economic Studies the cohort graduating in July 2016. The students were asked to fill in a questionnaire (included in the annex) designed to obtain their opinions on the relative importance of GA topics, which 


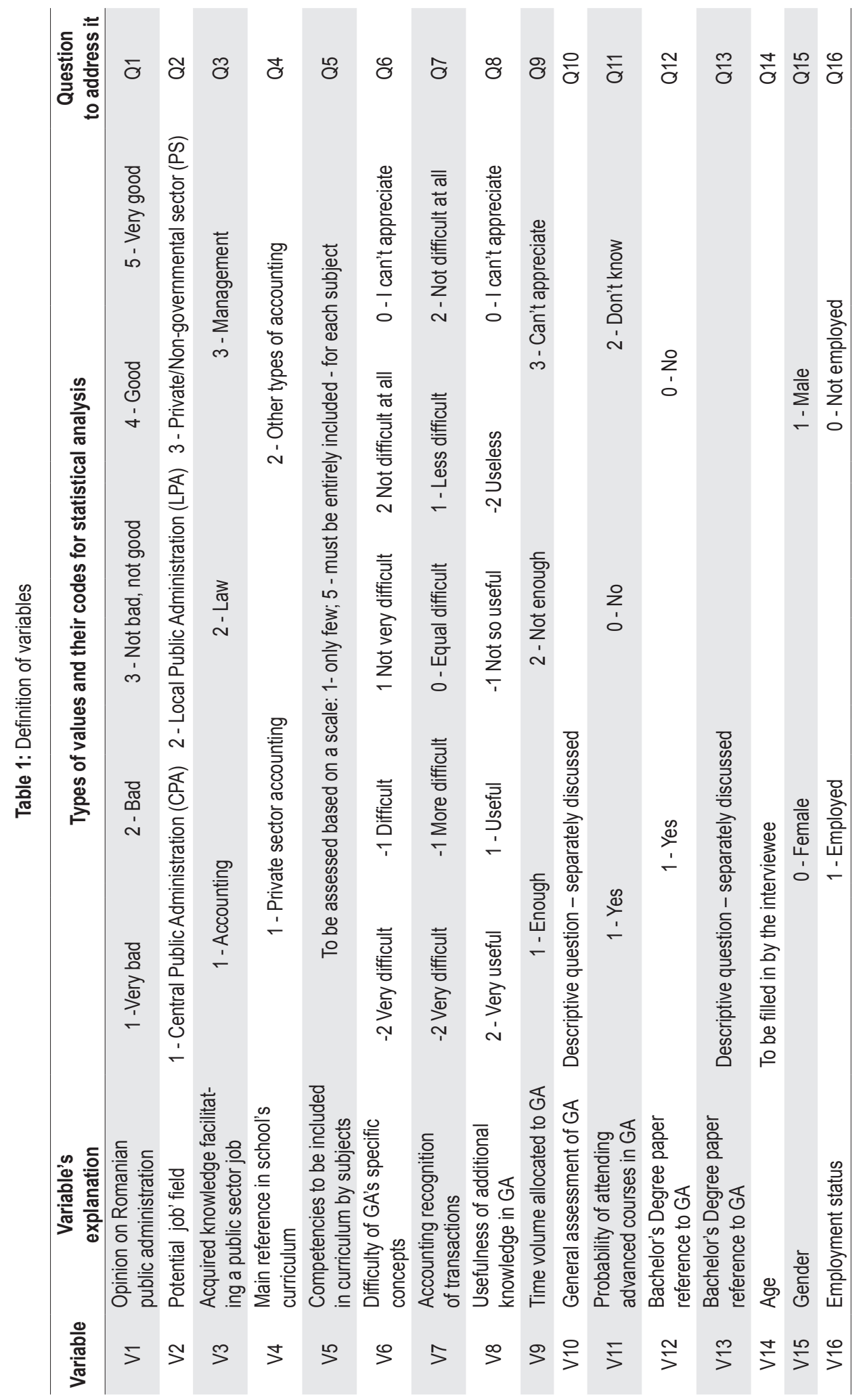


have been studied during the second semester of their final year. The questionnaire was filled in face-to-face, thus avoiding the risk of a low response rate, and it was delivered one month before the exam session; therefore, we can consider that their opinion was not influenced by the exam results. The questionnaire was designed based on the program's curricula as reference and questions were mainly closed-ended, but we aimed to test their general opinion on GA, so two open-ended questions were also included. In order to respect the ethical guidelines of conducting a survey, the questionnaires respected the anonymity criteria. The 16 questions delivered demographic data and undergraduate students' opinions over particularities and usefulness of this discipline, as well as their interest in GA and their view over the main competencies needed for an accounting professional in public administration.

The open-ended questions are separately discussed in the results section. Table 1 explains the variables and their codifications used in the analysis, as well as the questions they refer to.

\section{Empirical results}

This section is organized so that we answer to the three main objectives of the study by individually assessing the hypotheses we have presented in the section where the objectives were discussed. The $\mathrm{R}$ soft has been used to investigate the existence of statistical differences among several groups.

For studying the first objective, as described before, we have investigated six hypotheses and the results are detailed as follows.

Table 2: Frequencies table for Q1, Q2 and Q3

\begin{tabular}{|c|c|c|c|c|c|c|}
\hline $\begin{array}{c}\text { Contingency } \\
\text { table between } \\
\text { Q1, Q2 and Q3 }\end{array}$ & Absolute frequencies & Accounting & Juridical & Management & Total & $\begin{array}{c}\% \\
\text { of students }\end{array}$ \\
\hline \multirow{3}{*}{ Bad } & Central public admin (CPA) & 1 & 0 & 0 & 1 & $0 \%$ \\
\hline & Local public admin (LPA) & 3 & 1 & 0 & 4 & $1 \%$ \\
\hline & Private/Non-gov sector (PS) & 52 & 11 & 4 & 67 & $24 \%$ \\
\hline \multirow{3}{*}{ Good } & Central public admin (CPA) & 6 & 1 & 0 & 7 & $3 \%$ \\
\hline & Local public admin (LPA) & 2 & 1 & 0 & 3 & $1 \%$ \\
\hline & Private/Non-gov sector(PS) & 37 & 1 & 2 & 40 & $14 \%$ \\
\hline \multirow{3}{*}{$\begin{array}{c}\text { No_good_ } \\
\text { no_bad }\end{array}$} & Central public admin (CPA) & 12 & 3 & 0 & 15 & $5 \%$ \\
\hline & Local public admin (LPA) & 3 & 1 & 0 & 4 & $1 \%$ \\
\hline & Private/Non-gov sector (PS) & 109 & 15 & 1 & 125 & $45 \%$ \\
\hline \multirow{3}{*}{ Very_bad } & Central public admin (CPA) & 1 & 0 & 0 & 1 & $0 \%$ \\
\hline & Local public admin (LPA) & 0 & 0 & 0 & 0 & $0 \%$ \\
\hline & Private/Non-gov sector (PS) & 4 & 0 & 2 & 6 & $2 \%$ \\
\hline \multirow{3}{*}{ Very_good } & Central public admin (CPA) & 1 & 0 & 0 & 1 & $0 \%$ \\
\hline & Local public admin (LPA) & 3 & 0 & 0 & 3 & $1 \%$ \\
\hline & Private/Non-gov sector (PS) & 2 & 0 & 0 & 2 & $1 \%$ \\
\hline \multirow{3}{*}{$\begin{array}{c}\text { Total } \% \\
\text { of students }\end{array}$} & Central public admin (CPA) & $8 \%$ & $1 \%$ & $0 \%$ & & \\
\hline & Local public admin (LPA) & $4 \%$ & $1 \%$ & $0 \%$ & & \\
\hline & Private/Non-gov sector (PS) & $73 \%$ & $10 \%$ & $3 \%$ & & \\
\hline
\end{tabular}


Table 2 from above shows the frequencies table for Q1, Q2 and Q3. Several hypotheses are confirmed or infirmed:

- H1. There is a connection between undergraduate students' choice of being employed in the public administration and their opinion about this sector. (Q1-Q2) $\Rightarrow 14 \%$ of students choose to work in a private, non-governmental sector while they have a good opinion about public administration; $45 \%$ of students have a neutral opinion about public administration, but they choose also the private, non-governmental sector; $24 \%$ of students have a bad opinion about public administration and choose to work in the private, non-governmental sector.

- H.1.1. Undergraduate students' interest for getting a job in public administration is low $=>$ only $14 \%$ of students prefer to work in the public administration, while $86 \%$ would go to the private, non-governmental sector.

- H8. There is a connection between the typology of courses studied by undergraduate students and the choice of getting employed in the public administration. (Q2-Q3) $\Rightarrow>73 \%$ of students believe that accounting knowledge represents a must for working in the private, non-governmental sector; $10 \%$ of them think that legal knowledge is essential for the same working sector.

Table 3: Frequencies table for Q1, Q2, Q4 and Q16

\begin{tabular}{|c|c|c|c|c|c|c|c|}
\hline \multicolumn{3}{|c|}{ Contingency table between Q1,Q2,Q4 and Q16 } & \multirow{2}{*}{$\begin{array}{r}\text { Bad } \\
0\end{array}$} & \multirow{2}{*}{$\begin{array}{c}\text { Good } \\
2\end{array}$} & \multirow{2}{*}{$\begin{array}{c}\text { No_good } \\
\text { no_bad }\end{array}$} & \multirow{2}{*}{$\begin{array}{c}\text { Very_bad } \\
0\end{array}$} & \multirow{2}{*}{$\begin{array}{c}\text { Very_good } \\
1\end{array}$} \\
\hline \multirow{6}{*}{ Not_work } & \multirow{2}{*}{ CPA } & Companies's accounting & & & & & \\
\hline & & Other types of accounting & 1 & 0 & 5 & 0 & 0 \\
\hline & \multirow{2}{*}{ LPA } & Companies's accounting & 1 & 0 & 1 & 0 & 0 \\
\hline & & Other types of accounting & 0 & 0 & 2 & 0 & 2 \\
\hline & \multirow{2}{*}{ PS } & Companies's accounting & 23 & 10 & 32 & 1 & 2 \\
\hline & & Other types of accounting & 6 & 4 & 15 & 2 & 0 \\
\hline \multirow{6}{*}{ Work } & \multirow{2}{*}{ CPA } & Companies's accounting & 0 & 2 & 4 & 0 & 0 \\
\hline & & Other types of accounting & 0 & 3 & 3 & 1 & 0 \\
\hline & \multirow{2}{*}{ LPA } & Companies's accounting & 2 & 1 & 1 & 0 & 1 \\
\hline & & Other types of accounting & 1 & 2 & 0 & 0 & 0 \\
\hline & \multirow{2}{*}{ PS } & Companies's accounting & 33 & 15 & 52 & 2 & 0 \\
\hline & & Other types of accounting & 5 & 11 & 26 & 1 & 0 \\
\hline & & \%work & $11 \%$ & $6 \%$ & $21 \%$ & $1 \%$ & $2 \%$ \\
\hline \multicolumn{3}{|r|}{$\%$ not work } & $15 \%$ & $12 \%$ & $31 \%$ & $1 \%$ & $0 \%$ \\
\hline & \multirow{2}{*}{ CPA } & Companies's accounting & $4 \%$ & & & & \\
\hline & & Other types of accounting & $5 \%$ & & & & \\
\hline & \multirow{2}{*}{ LPA } & Companies's accounting & $3 \%$ & & & & \\
\hline & & Other types of accounting & $3 \%$ & & & & \\
\hline & \multirow{2}{*}{ PS } & Companies's accounting & $61 \%$ & & & & \\
\hline & & Other types of accounting & $25 \%$ & & & & \\
\hline
\end{tabular}

Table 3 from above shows the results of a frequency table between Q1, Q2, Q4 and Q16. These results are used to evaluate the following hypotheses:

- H2. There is a connection between undergraduate students' choice of being employed in the public administration and the typology of courses in their pro- 
gram's curricula. (Q2-Q4) $\Rightarrow 61 \%$ of total students prefer to work in the private or non-governmental sectors while the courses in their program's curricula refer to the accounting of companies;

- H6. There is a connection between undergraduate students' employment status and their opinion about public administration. (Q1-Q16) $\Rightarrow$ except the neutral opinion (for $52 \%$ of students), $15 \%$ of students that are not employed have a bad opinion about public administration, $12 \%$ have a good opinion, while $11 \%$ of students that are employed have a bad opinion about public administration, and $6 \%$ have a good opinion.

We have continued with the second main objective of the study, namely to investigate if undergraduate students' interest for GA might be connected with the time allocated in the program's curricula. For studying this aspect, we have elaborated four hypotheses, as presented in the previous section.

Table 4: Frequencies table for Q6, Q7 and Q9

\begin{tabular}{|c|c|c|c|c|c|c|c|}
\hline \multicolumn{2}{|c|}{ Students' assessment of GA's concepts } & \multirow{2}{*}{$\begin{array}{c}\begin{array}{c}\text { Cannot_ } \\
\text { appreciate }\end{array} \\
0\end{array}$} & \multirow{2}{*}{$\begin{array}{c}\text { Difficult } \\
1\end{array}$} & \multirow{2}{*}{$\begin{array}{c}\begin{array}{c}\text { Less_ } \\
\text { difficult }\end{array} \\
2\end{array}$} & \multirow{2}{*}{$\begin{array}{c}\frac{\text { Not_ }}{\text { difficult }} \\
1\end{array}$} & \multirow{2}{*}{$\begin{array}{c}\begin{array}{c}\text { Very_ } \\
\text { difficult }\end{array} \\
0\end{array}$} & \multirow{2}{*}{$\begin{array}{c}\% \text { of total } \\
1 \%\end{array}$} \\
\hline & Cannot_appreciate & & & & & & \\
\hline \multirow[t]{3}{*}{ Almost_the_same } & Enough_time & 0 & 10 & 31 & 3 & 0 & $16 \%$ \\
\hline & Not_enough_time & 0 & 10 & 37 & 6 & 0 & $19 \%$ \\
\hline & Cannot_appreciate & 0 & 0 & 0 & 0 & 0 & $0 \%$ \\
\hline \multirow[t]{3}{*}{ Easier } & Enough_time & 0 & 3 & 1 & 1 & 1 & $2 \%$ \\
\hline & Not_enough_time & 0 & 3 & 3 & 0 & 0 & $2 \%$ \\
\hline & Cannot_appreciate & 0 & 3 & 3 & 0 & 0 & $2 \%$ \\
\hline \multirow[t]{3}{*}{ More_dificult } & Enough_time & 0 & 16 & 19 & 1 & 0 & $13 \%$ \\
\hline & Not_enough_time & 2 & 61 & 42 & 1 & 4 & $39 \%$ \\
\hline & Cannot_appreciate & 0 & 0 & 1 & 0 & 0 & $0 \%$ \\
\hline \multirow[t]{3}{*}{ Very_difficult } & Enough_time & 0 & 0 & 0 & 0 & 2 & $1 \%$ \\
\hline & Not_enough_time & 0 & 8 & 1 & 0 & 2 & $4 \%$ \\
\hline & Cannot_appreciate & $0 \%$ & $1 \%$ & $2 \%$ & $0 \%$ & $0 \%$ & \\
\hline \multirow[t]{2}{*}{$\%$ of total } & Enough_time & $0 \%$ & $10 \%$ & $18 \%$ & $2 \%$ & $1 \%$ & \\
\hline & Not_enough_time & $1 \%$ & $29 \%$ & $30 \%$ & $3 \%$ & $2 \%$ & \\
\hline
\end{tabular}

The table from above answers to the following hypotheses:

- H3. There is a connection between undergraduate students' assessment of GA's particular concepts and the time volume allocated to this discipline. (Q6-Q9) $\Rightarrow$ $29 \%$ of students believe that there is not enough time allocated to the discipline and that the particular concepts are difficult; $30 \%$ of students believe the same about allocated time, but consider that particular concepts are not very difficult (less difficult).

- H4. There is a connection between the undergraduate students' assessment of transactions' recognition in GA and the time volume allocated to this discipline. (Q7-Q9) $\Rightarrow 39 \%$ of students who believe there is not enough time allocated to the discipline also see the assessment of transactions' recognition in GA as more difficult than the accounting of companies, while $19 \%$ of the same category of 
students believe that the assessment of transactions' recognition in GA is almost the same as the accounting of companies in terms of study difficulty.

Table 5: Frequencies table for $\mathrm{Q} 8$ and $\mathrm{Q} 11$

\begin{tabular}{lcccc}
\hline $\begin{array}{l}\text { The usefulness of courses and the possibility } \\
\text { of attending advanced courses }\end{array}$ & Do not know & No & Yes & $\%$ of total \\
\hline Cannot_appreciate & 5 & 12 & 2 & $7 \%$ \\
Less_useful & 19 & 42 & 6 & $24 \%$ \\
Not_useful & 1 & 11 & 0 & $4 \%$ \\
Useful & 79 & 73 & 14 & $59 \%$ \\
Very_useful & 6 & 3 & 6 & $5 \%$ \\
\% of total & $39 \%$ & $51 \%$ & $10 \%$ & \\
\hline
\end{tabular}

Table 5 shows the confirmation or not of the following hypothesis:

- H5. There is a connection between the undergraduate students' choice for advanced GA courses and the usefulness of studying adjacent information. (Q8Q11) $=>60 \%$ of students believe that there is a need to study other disciplines and only $10 \%$ of them will take advanced courses such as Masters or PhDs.

Continuing our research, we have answered to the last important objective of our study, namely we will examine the opinion of the undergraduate students regarding the connection between the competencies delivered by the program's curricula and the labor market requirements.

Table 6: Students' opinion about competencies by employment status

\begin{tabular}{|c|c|c|c|c|c|c|c|c|}
\hline & & High & $\mathrm{Bad}$ & Medium & Very_high & Very_bad & $\begin{array}{c}\% \text { (high+very_high) } \\
\text { of total }\end{array}$ & $\begin{array}{c}\% \text { (bad+very_bad) } \\
\text { of total }\end{array}$ \\
\hline \multirow{2}{*}{ Communication } & not_work & 24 & 11 & 21 & 43 & 14 & $24 \%$ & $9 \%$ \\
\hline & work & 28 & 18 & 32 & 72 & 16 & $36 \%$ & $12 \%$ \\
\hline \multirow{2}{*}{ Mangement } & not_work & 23 & 19 & 29 & 23 & 19 & $16 \%$ & $14 \%$ \\
\hline & work & 39 & 24 & 50 & 25 & 28 & $23 \%$ & $19 \%$ \\
\hline \multirow{2}{*}{ Law } & not_work & 35 & 8 & 24 & 37 & 9 & $26 \%$ & $6 \%$ \\
\hline & work & 50 & 12 & 42 & 51 & 11 & $36 \%$ & $8 \%$ \\
\hline Companies' & not_work & 19 & 2 & 8 & 81 & 3 & $36 \%$ & $2 \%$ \\
\hline accounting & work & 22 & 5 & 12 & 118 & 9 & $50 \%$ & $5 \%$ \\
\hline \multirow{2}{*}{$\begin{array}{l}\text { Others types } \\
\text { of accounting }\end{array}$} & not_work & 33 & 8 & 23 & 43 & 6 & $27 \%$ & $5 \%$ \\
\hline & work & 46 & 13 & 25 & 79 & 3 & $45 \%$ & $6 \%$ \\
\hline \multirow{2}{*}{ IT } & not_work & 26 & 11 & 27 & 34 & 15 & $22 \%$ & $9 \%$ \\
\hline & work & 51 & 17 & 27 & 56 & 15 & $38 \%$ & $11 \%$ \\
\hline \multirow{2}{*}{ Taxation } & not_work & 36 & 5 & 14 & 56 & 2 & $33 \%$ & $3 \%$ \\
\hline & work & 52 & 11 & 22 & 79 & 2 & $47 \%$ & $5 \%$ \\
\hline
\end{tabular}

The table above provides the answer of the hypothesis H7:

- H7. There is a connection between the undergraduate students' employment status and the mandatory competencies to be included in the curricula (Q5-Q16) $\Rightarrow$ the majority of employed students consider that taxation, information technology and accounting (companies and other entities) have a high or very high importance and should be included in the curricula; most of unemployed students 
believe that law competencies, accounting and taxation are important and should be included in the curricula. The difference between opinions of employed and unemployed students is that, while employed students consider IT as an important competence, the unemployed students consider law as an important competence and this shows the discrepancy between what students believe is important for the labor market and what is really important and required by employers, once they start working.

Table 7: Students' opinion about competencies delivered by university

\begin{tabular}{lcccccc}
\hline & High & Bad & Medium & $\begin{array}{c}\text { Very_ } \\
\text { high }\end{array}$ & $\begin{array}{c}\text { Very_ } \\
\text { bad }\end{array}$ & $\begin{array}{c}\% \text { (high+very_high) } \\
\text { of total }\end{array}$ \\
\hline Communication & 52 & 29 & 53 & 115 & 30 & $60 \%$ \\
Management & 62 & 43 & 79 & 48 & 47 & $39 \%$ \\
Law & 85 & 20 & 66 & 88 & 20 & $\mathbf{6 2 \%}$ \\
Companies_Accounting & 41 & 7 & 20 & 199 & 12 & $\mathbf{8 6 \%}$ \\
Others_Accounting & 79 & 21 & 48 & 122 & 9 & $\mathbf{7 2 \%}$ \\
IT & 77 & 28 & 54 & 90 & 30 & $\mathbf{6 0 \%}$ \\
Taxation & 88 & 16 & 36 & 135 & 4 & $\mathbf{8 0 \%}$ \\
\hline
\end{tabular}

The above table shows that the most important competencies delivered by the program's curricula must be accounting (both for companies and other entities), taxation and law. It is interesting to analyze the students' vision about management, because they do not consider this competence as an important one that could be developed by school.

Another analysis performed concerned Pearson's Chi-squared results.

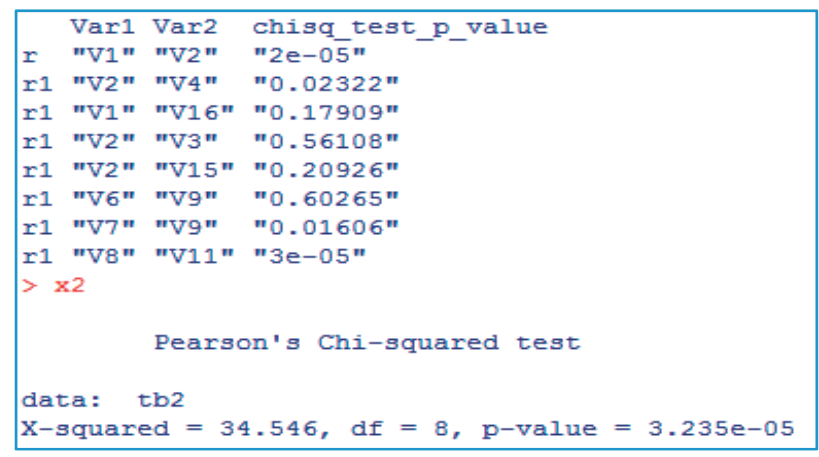

Figure 1: Pearson's Chi-squared test results

Figure 1 from above show the Pearson's Chi-squared test results applied on couples of variables (defined by contingency tables) in order to identify if the variables are independent of each other. The output called $x 2$ shows the extended Pearson's Chi-squared test results for variables V8 and V11, while the table above this output is the synthesis of 8 tests, represented by variable 1 (Var1), variable 2 (Var2) and the test's associated p-value.

This R output comes to confirm or infirm the hypotheses presented for each defined objective. We could observe a dependency between V1 and V2 (students' opin- 
ion about public administration and students' choice of being employed in the public sector), V2 and V4 (students' choice of being employed in the public sector and the predominant courses in their program's curricula), V7 and V9 (students' assessment of transactions' recognition in GA and the time volume allocated to this discipline), V8 and V11 (the usefulness of studying adjacent information and students' choice for advanced GA courses), because the p-value associated to Pearson's Chi-squared test is lower than 0.05 , at a level of significance of $95 \%$.

On the other hand, it is interesting that variables like V1 and V16 (students' opinion about the public sector and their employment status), V2 and V3 (the choice of getting employed in the public sector and the typology of the predominant accounting courses studied by undergraduate students), V2 and V15 (the choice of getting employed in the public sector and the respondents' gender), V6 and V9 (students' assessment of GA's particular concepts and the time volume allocated to this discipline) are independent.

In addition, we used another method to analyze contingency tables like the correspondence analysis.

The correspondence analysis may be applied on contingency tables that are composed of variables V1 and V2 (image 1), V7 and V9 (image 2), V8 and V11 (image 3), as a result of significant dependency between rows and columns, proved by Pearson's Chi-squared tests. From this point of view, the correspondence analysis results (Figure 2 above) may be interpreted in terms of the symmetric plot or biplot of rows and columns (plot realized in two dimensions that explain all variability of data). Because only the distance between rows or the distance between columns may be interpreted, it is possible to draw the following conclusions:

- students who would choose to work in the local public administration often have a very good opinion about public administration, while students who would choose the central public administration have a very bad opinion about public administration.

- students who believe that transactions' recognition in GA is easier comparing to companies' accounting consider that there is enough time volume allocated to this discipline, while students who cannot appreciate the time allocated consider that transactions' recognition in GA is very difficult compared with companies' accounting; and

- students who find studying adjacent information very useful would take into consideration to continue advanced GA courses (like Master or PHD), while students who think that studying adjacent information is useful are still undecided about continuing the advanced GA courses.

Open-ended questions generated a number of interesting responses. Thus, 68 of the respondents consider that GA is more difficult than private companies' accounting that they have studied during the first two years of accounting school. Another 28 respondents think of GA as very useful in their future professional career, while 11 respondents consider it more complex than what they have previously studied. The 


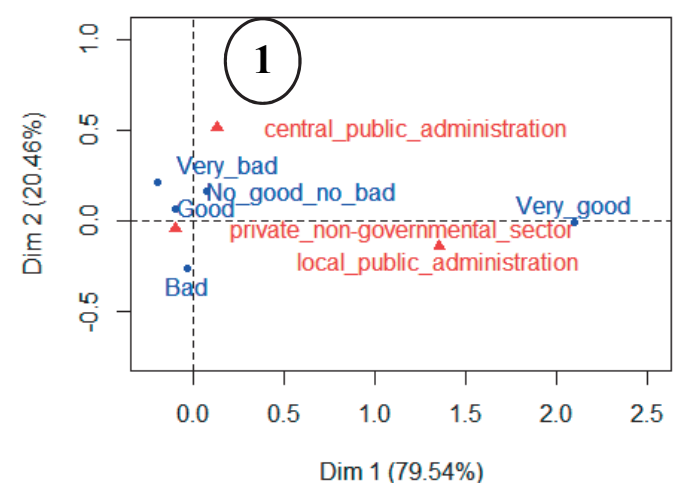

CA factor map

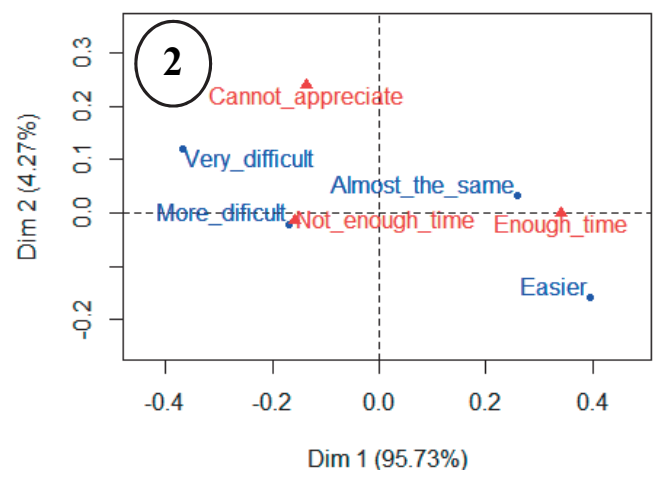

CA factor map

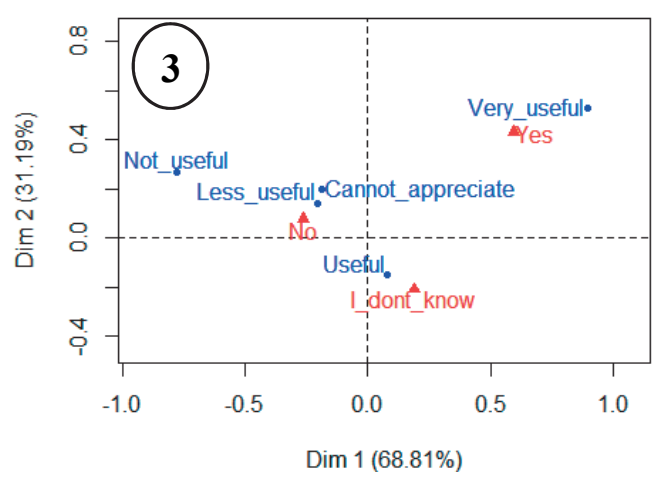

Figure 2: Correspondence analysis - symmetric plot for V1 and V2, V7 and V9, V8 and V11

number of those respondents who consider GA useless, boring or illogical (compared to private companies' accounting) is relatively small for the dimension of the sample that is 10 individuals. The rest of the sample delivered isolated answers leading to a general view over GA as a relevant, complex, detailed discipline that needs more time 
to be studied and understood than private companies' accounting. What appears to be very interesting in these open answers is that only one individual out of 283 in the sample considered GA useless because of the low level of salaries in the public sector and thus of no interest for future graduates as a possible workplace option.

\section{Conclusions, limits and future research}

This research has approached a relatively limited theme in what the dedicated literature is concerned, considering the integrated relation between public administration sector - future accounting professionals - university curricula.

The first objective of the research is considered to be fulfilled, that is undergraduate students' decision of being employed in public administration is determined by their opinion towards this domain and the curricula's orientation on public sector particularities. The management of the public administration sector and the academic environment are fundamental for the creation and promotion of the motivational and professional framework so that future graduates are oriented towards the labor market in the public sector. In this respect, the option of future graduates for being employed in public administration depends on the preponderance of the disciplines in the program's curricula. $61 \%$ of total students prefer to work in the private or non-governmental sectors while the courses in their program's curricula refer to the accounting of companies.

The second objective of the study was to investigate if undergraduate students' interest for GA might be connected with the time allocated in the program's curricula. $39 \%$ of students believe there is not enough time allocated to the discipline and also see the assessment of transactions' recognition in GA as more difficult than the companies' accounting, while $19 \%$ of the same category of students believe that the assessment of transactions' recognition in GA is almost the same as the accounting of companies in terms of study difficulty. In terms of a relation between the undergraduate students' choice for advanced GA courses and the usefulness of studying adjacent information, $60 \%$ of students believe that there is a need to study other disciplines and only $10 \%$ of them will take advanced courses. The inclusion of GA discipline in the second year of study's curricula should also lead undergraduates towards a Bachelor's degree paper with a GA subject.

As for the third objective - opinion of the undergraduate students on the connection between competencies delivered by the program's curricula and the labor market requirements - the analysis reveals that the most important competencies delivered by the program's curricula must be accounting (both for companies and other entities), taxation and law. It is interesting to analyze the students' vision about management, because they do not consider this competence as an important one that could be developed by school.

The limits of our research concern the sample area referring only to undergraduates of AMIS school from the Bucharest University of Economic Studies. Nevertheless, there is no risk in altering the research results considering that the Bucharest 
University of Economic Studies is the only Romanian university having exclusively economic specializations, activating for more than a century in the Romanian academic environment and that AMIS school is representative for the number of undergraduates/graduates. As future research directions, we intend to continue the research by investigating other aspects concerning the development of competencies for future professionals in public administration sector.

\section{References:}

1. Agenția Națională a Funcționarilor Publici, 'Corelarea învățării cu piața muncii. Raport de cercetare', 2015, [Online] available at http://www.anfp.gov.ro/R/Doc/2015 /Studii\%20si\%20prezentari/sinteza\%20Raport\%20studiu\%20CIPM.pdf, accessed on September 20, 2018.

2. Albrecht, W.S. and Sack, R.J., Accounting Education: Charting the Course through a Perilous Future, Sarasota: American Accounting Association, 2000.

3. Chan, J.L., 'Government Accounting: An Assessment of Theory, Purpose and Standards', 2003, Public Money and Management, vol. 23, no. 1, pp. 13-20.

4. Daniels, B.W., Gupta, R.D. and Pridgen, A.K., 'Faculty Perspectives on Governmental and Nonprofit Accounting Topics', 2007, The Accounting Educators' Journal, vol. 17, pp. $1-12$.

5. Deaconu, A., Nistor, C.S. and Filip, C., 'The Impact of Accrual Accounting on Public Sector Management: An Exploratory Study for Romania', 2011, Transylvanian Review of Administrative Sciences, vol. 32E, pp. 74-97.

6. Henry, B.K., 'A Survey of Governmental Accounting Education Studies', 2005, Journal of Public Budgeting, Accounting \& Financial Management, vol. 17, no. 2, pp. 166-179.

7. Hințea, C.E., Profiroiu, M.C. and Țiclău, T.C., 'Strategic Planning and Public Management Reform: The Case of Romania', 2015, Transylvanian Review of Administrative Sciences, Special Issue, pp. 30-44.

8. Hurt, B., 'Teaching What Matters: A New Conception of Accounting Education', 2007, Journal of Education for Business, vol. 82, no. 5, pp. 295-299.

9. Miller, G.J., 'Trends and Challenges in Governmental Accounting Education', 2006, Journal of Government Financial Management, vol. 55, no. 2, pp. 20-24.

10. Pitulice, I.C. and Ștefănescu, A., 'Research on the Accurate Image Supplied by the Financial Reporting. The Case of the Local Public Administration Entities form Romania', International Conference on Accounting and Management Information Systems, Bucharest, 8-9 June 2016.

11. Profiroiu, A.G., 'Lecturer and Student Perspective Regarding Teaching Public Administration in Romania', 2013, Transylvanian Review of Administrative Sciences, Special Issue, pp. 141-155.

12. Tiron-Tudor, A., 'Romanian Public Institutions Financial Statements on the Way of Harmonization with IPSAS', 2010, Accounting and Management Information Systems, vol. 9, no. 3, pp. 422-447.

13. Tiron-Tudor, A., Nistor, C.S. and Carstea, A., 'The Way of Public Institutions to Accrual Accounting - Case Study Romania', 2012, EuroEconomica, vol. 31, no. 3, pp. 57-74.

14. Wilson, E., 'An Historical Perspective on Governmental Accounting Education', 2013, Journal of Accounting Education, vol. 31, no. 6, pp. 244-251. 


\section{ANNEX \\ QUESTIONNAIRE FOR TESTING STUDENTS' PERCEPTION ON GOVERNMENT ACCOUNTING}

1. What is your opinion on Romanian public administration?

(1 - very bad; 2 - bad; 3 - not bad, not good; 4 - good; 5 - very good)

Very good; $\quad$ Good; $\quad$ Not bad, not good; $\quad$ Bad; $\quad$ Very bad.

2. Once you graduate, would you choose to get a job in:
a. central public administration
b. local public administration (CPA);
(LPA);
c. private/non-governmental sector (PS).

3. From the attended courses, which do you think delivered the most important knowledge that would facilitate a potential job in the public sector (only one option accepted).
a. accounting knowledge;
b. law/juridical knowledge;
c. management knowledge.

4. Courses in your school's curricula are mainly referring to: (only one option accepted)

\begin{tabular}{|l|l|}
\hline a. private sector accounting; & \\
\hline $\begin{array}{l}\text { b. accounting for other types of entities (financial institutions, public sector entities, } \\
\text { not-for-profit entities, authorized professionals, etc.). }\end{array}$ & \\
\hline
\end{tabular}

5. The following abilities/competencies should be included in the school's curricula? (Assess them based on a scale: 1- only few should be included; 5 - must be entirely included).

\begin{tabular}{|l|l|}
\hline Communication skills & \\
\hline Management & \\
\hline Law/juridical (e.g., interpretation of legal regulations) & \\
\hline Private companies accounting & \\
\hline $\begin{array}{l}\text { Accounting for other types of entities (financial institutions, public sector entities, } \\
\text { not-for-profit entities, authorized professionals, etc.) }\end{array}$ & \\
\hline IT & \\
\hline Taxation & \\
\hline
\end{tabular}

6. When studying Government Accounting, its specific concepts seem to be (financing stages, public domain assets' recognition, etc.):
a. Very difficult;
b. Difficult;
c. Not very difficult;
d. Not difficult at all;
e. I can't appreciate.

7. By reference to private companies' accounting, accounting recognition of Government Accounting's transaction is:
a. Very difficult;
b. More difficult;
c. Equal difficulty;
d. Less difficult;
e. Not difficult at all. 
8. Do you consider as useful additional knowledge in Government Accounting courses (as Prevention Financial Control, budgeting process, Engagement, Liquidation, Ordering of paying and Payment of budgetary expenses)?
a. Very useful;
b. Useful;
c. Not so useful;
d. Useless;
e. I can't appreciate.

9. How would you appreciate the time volume allocated to the Government Accounting' course?

a) Enough for understanding and practical use of concepts;

b) Not enough for understanding and practical use of concepts;

c) I can't appreciate.

10.Based on what you have studied so far, how would you appreciate Government Accounting (by referring to private sector accounting studied so far)?

11.Would you consider the possibility of attending advanced courses (post-graduate) in Government Accounting? a. Yes; b. No; c. I don't know.

12.The main theme of your Bachelor's Degree paper refers to Government Accounting? a. Yes; b. No.

If the answer is $b$ ), then please answer also question 13 .

13.If Government Accounting had been studied in the second year, would you have considered it when choosing Bachelor's Degree paper?

14. Your age: years

15. You are: a. Female; b. Male.

16. At present, you have are employed: a. Yes; b. No. 